\title{
STRATEGI PENGEMBANGAN OBJEK WISATA PEMANDIAN LUBUK MATA KUCING KOTA PADANG PANJANG
}

\section{YOLVERI \\ Dosen Akademi Pariwisata Paramitha Bukittinggi}

\begin{abstract}
The city government of Padang Panjang has developed several tourism objects, one of which is the Lubuk Mata Kucing bath because there are still not many tourism who have not seen the object, due to the location which is on the outskirts of the city and road directions to tourism objects are still lacking, then indirectly affect the level of tourism visits. The Lubuk Mata Kucing bath is indeed very minimal promotion and exposes tourism objects to the crowd, so you do not see this beautiful tourism attraction, in addition to the lack of promotion in the facilities section. The Indonesian government has tried to make Indonesia one of the tourism destinations for tourism and make Indonesia the main destination for tourism, tourism who visit many tourism objects in Indonesia automatically improve the economy of local residents and foreign exchange, as is being done by the Padang government. Panjang In making improvements to one of the tourism objects, namely the Lubuk Mata Kucing bath, to be a better tourism attraction. The development of the world of tourism and increased competition in the Tourism Industry of the Padang Panjang City Government, especially the Tourism Office, should carry out various development strategies so that tourism in the City of Padang Panjang is not left behind as one of the Lubuk Mata Kucing bathing objects that can develop and attract tourism to visit. The Municipal Government of Padang Panjang cooperates with other parties that are expected to increase the level of tourist visits.
\end{abstract}

Keywords: Tourism, Strategy, Development.

Abstrak: Pemerintah Kota Padang Panjang telah mengembangkan beberapa obyek wisata salah satunya adalah Pemandian Lubuk Mata Kucing karena masih belum banyak wisata yang belum melihat obyek tersebut, dikarenakan letaknya yang berada dipinggiran kota dan petunjuk jalan menuju obyek wisata yang masih kurang, maka secara tidak langsung mempengaruhi tingkat kunjungan wisata. Pemandian Lubuk Mata Kucing memang sangat minim promosi dan mengekspos objek wisata kepada orang banyak, sehingga objek wisata yang indah ini tidak Anda lihat, selain kurangnya promosi di bagian fasilitas. Pemerintah Indonesia telah berusaha menjadikan Indonesia sebagai salah satu destinasi pariwisata pariwisata dan menjadikan Indonesia sebagai tujuan utama pariwisata, pariwisata yang banyak mengunjungi objek wisata di Indonesia otomatis meningkatkan perekonomian penduduk lokal dan devisa negara, seperti yang dilakukan oleh Pemerintah Padang. pemerintah. Panjang Dalam melakukan pembenahan pada salah satu objek wisata yaitu Pemandian Kucing Lubuk Mata, agar menjadi objek wisata yang lebih baik. Perkembangan dunia pariwisata dan meningkatnya persaingan di Industri Pariwisata Pemerintah Kota Padang Panjang khususnya Dinas Pariwisata seharusnya melakukan berbagai strategi pengembangan agar pariwisata di Kota Padang Panjang tidak ketinggalan sebagai salah satu Lubuk Obyek pemandian Mata Kucing yang dapat mengembangkan dan menarik wisata untuk dikunjungi. Pemerintah Kota Padang Panjang menjalin kerja sama dengan pihak lain yang diharapkan dapat meningkatkan tingkat kunjungan wisatawan.

Kata Kunci: Pariwisata, Strategi, Pengembangan. 


\section{A. Pendahuluan}

Salah satu daerah tujuan wisata yang ada di Sumatera Barat yaitu kota Padang Panjang, yang dinilai mempunyai potensi yang cukup besar dalam memberi kontribusi terhadap peningkatan pariwisata di Sumatera Barat. Dengan kondisi tersebut pemerintahan kota Padang Panjang di Pacu untuk meningkatkan kualitas kawasan wisata dengan pembangunan dan perbaikan sarana dan prasarana penunjang pariwisata, agar wisatawan yang berkunjung semakin meningkat. Pemerintah kota Padang Panjang telah melakukan pengembangan terhadap beberapa objek wisata, salah satu diantaranya adalah pemandian Lubuk Mata Kucing karena masih belum banyak wisatawan yang belum mengetahui objek tersebut disebabkan lokasi yang berada di pinggiran kota dan petunjuk jalan untuk ke objek wisata yang masih kurang, maka secara tidak langsung mempengaruhi tingkat kunjungan wisatawan.

Pemandian Lubuk Mata Kucing memang sangat minim sekali promosi dan mengekspos objek wisata kekhalayak ramai sehingga wisatawan tidak mengetahui objek wisata yang indah ini, selain promosi yang kurang dibagian fasilitas pun juga sangat kurang. Pemerintah sekarang ini sudah mulai membenahi sarana dan prasarana agar objek ini menjadi salah satu tujuan wisata yang diminati wisatawan. Bicara tentang pengembangan yang dilakukan oleh pemerintah terhadap objek wisata pemerintah Sumatera Barat telah terlebih dahulu membenahi pariwisata yang ada di Sumatera Barat. Secara perlahan pun wisatawan mulai mengenal dan mengetahui objek-objek wisata yang ada di Sumatera Barat, sehingga meningkatkan kunjungan wisatawan ke objek wisata yang ad di Sumatera Barat.

Perkembangan pariwisata di Sumatera Barat saat baik ditunjukkan oleh kunjungan wisatawan selama 2000-2005. Jumlah wisatawan yang datang ke Sumatera Barat meningkat dari 381.979 orang pada tahun 2000 menjadi 4.360 .361 orang pada tahun 2005. Gambaran ini memperlihatkan bahwa pariwisata memiliki prospek yang cukup besar sebagai kekuatan ekonomi di Sumatera Barat. Kondisi geografis di Sumatera Barat secara topografis adalah bertanah landai, datar hingga tinggi mulai dari 0 sampai lebih dari 100 meter diatas permukaan laut. Bagian barat berhadapan dengan pantai Samudra Hindia dengan Teluk Bayur sebagai pelabuhan landai dan memiliki daya tarik tersendiri dan di bagian timur dengan lereng bergelombang antara 0-40 yang dijadikan daerah kawasan lindung. Keindahan alam Sumatera Barat dengan objekobjek yang masih alamiah yang tidak kalah dengan objek wisata disaerah lain. Hal yang perlu di lakukan untuk perancangan pembangunan kawasan pariwisata yaitu: a) Pusat kegiatan wisata dimana para wisatawan akan berkunjung; dan b) penetapan zona-zona perdagangan, pemukiman, pendidikan, pemerintahan, perkantoran dan yang lainnya sebagai pendukung pariwisata itu sendiri.

Dengan dilakukan itu maka akan menjadikan Sumatera Barat menjadi daerah Pariwisata yang saat terstruktur dan menjadi daerah yang menjadi pilihan bagi wisatawan, Pariwisata Sumatera Barat jika dibandingkan dengan Pariwisata di Indonesia masih sangat ketinggalan, Pariwisata di Indonesia menempati urutan ketiga pada tahun 2009 dalam hal penerimaan devisa setelah komoditi minyak dan gas bumi. Berdasarkan data tahun 2014 jumlah wisatawan mancanegara yang dating ke Indonesia sebesar 9,4 juta. Kekayaan alam dan budaya merupakan komponen penting dalam pariwisata di Indonesia, dengan memiliki iklim yang tropis 17.508 pulau, serta garis pantai terpanjang ketiga setelah Kanada dan Uni Eropa dan termasuk negara kepulauan tersebar dan berpenduduk terbanyak di dunia. Indonesia memiliki kawasan terumbu karang terkaya di dunia dengan lebih dari $18 \%$ terumbu karang dunia, serta lebih dari 3.000 spesies ikan, 590 jenis karang batu, 2.500 jenis moluska dan 1.500 jenis udang- 
udangan, dengan kekayaan biota laut ini telah menciptakan sekitar 600 titik tempat menyelam yang tersebar dari Sabang sampai Marauke. Indonesia juga memiliki lebih dari 400 gunung berapi dan 140 diantaranya termasuk gunung berapi aktif. Tempattempat wisata lain yang didukung oleh wisata budaya yang mencerminkan sejarah dan keberagaman etnis Indonesia yang dinamis dengan 719 bahasa daerah yang dituturkan di seluruh kepulauan.

Secara factual pembangunan Pariwisata nasional dapat dikatakan sentralistik sehingga memberikan gangguan kemandirian dalam perencanaan dan pembangunan yang dilaksanakan di daerah-daerah, dan kurang nya keberanian untuk melakukan perubahan kearah yang lebih baik, maka dari itu kita harus mendukung perencanaan dan pembangunan yang dilakukan oleh pemerintah agar semua tujuan baik tersebut bisa terlaksanakan dengan baik. Agar bisa menarik wisatawan agar bisa berkunjung dan menjadikan Indonesia sebagai salah satu tujuan wisata dari wisatawan dan menjadikan Indonesia sebagai tujuan utama bagi wisatawan, apabila wisatawan banyak mengunjungi objek-objek wisata yang ada di Indonesia otomatis memperbaiki perekonomian warga sekitar dan devisa negara, seperti yang tengah dilakukan pemerintah Padang Panjang dalam melakukan pembenahan terhadap salah satu objek wisata yaitu objek wisata pemandian Lubuk Mata Kucing unruk menjadikan objek wisata tersebut lebih baik.

\section{B. Metodologi Penelitian}

Berdasarkan uraian dan alasan diatas, maka metodologi pebelitian ini membahas rumusan masalah terkait, bagaimana strategi pengembangan objek wisata pemandian Lubuk Mata Kucing di Padang Panjang? dan faktor apa saja yang menjadi penghalang perkembangan objek wisata pemandian Lubuk Mata Kucing di Padang Panjang?

\section{Hasil dan Pembahasan}

\section{Strategi Pengembangan Objek Wisata Pemandian Lubuk Mata Kucing Dari Segi Kerja Sama Dengan Pihak Lain.}

Seiring berkembangnya dunia pariwisata dan semakin tingginya persaingan di Industri Pariwisata Pemerintah Kota Padang Panjang terutama Dinas Pariwisata sudah semestinya melakukan berbagai macam strategi pengembangan agar Pariwisata di Kota Padang Panjang tidak tertinggal salah satu nya objek wisata pemandian Lubuk Mata Kucing supaya bisa berkembang dan menarik wisatawan untuk berkunjung, Untuk itu Pemerintah Kota Padang Panjang melakukan kerja sama dengan pihak-pihak yang diharapkan bisa meningkatkan tingkat kunjungan wisatawan antara lainnya: Dengan Pihak Swasta. Mengadakan kerjasama dengan pihak Biro Perjalanan Wisata atau Tour \& Travel. BPW itu mempunyai pengertian yaitu perusahaan yang menyelenggarakan kegiatan paket wisata dan agen perjalanan, yang mana pihak Tour \& Travel memasukkan objek wisata Pemandian Lubuk Mata Kucing sebagai salah satu destinasi yang akan dikunjungi wisatawan, dengan cara ini lambat laun wisatawan akan mengetahui objek wisata pemandian Lubuk Mata Kucing, dan tidak sedikit juga wisatawan asing maupun local yang mengunjungi objek wisata pemandian Lubuk Mata Kucing bersama pemandu wisata dari Tour \& Travel. Kerjasama ini akan menguntungkan antara pihak pemerintah dan swasta.

Dengan Masyarakat Setempat. Mengadakan kerjasama dengan penduduk setempat agar objek wisata menjadi aman dan terkendali, dan masyarakat pun bisa juga berjualan di dalam lokasi tersebut, itu akan menjadi keuntungan bagi masyarakat dari 
segi perekonomiannya, tetapi harus menjaga kebersihan local objek wisata agar lokasi objek tetap bersih dan tertata rapi.

\section{Strategi Pengembangan Objek Wisata Lubuk Mata Kucing Dari Segi Kelengkapan}

Didalam pengembangan objek wisata ada beberapa hal yang harus di perhatikan sebagai berikut: Membuat Loket Resmi Dan Tiket Masuk Yang Unik. Loket merupakan tempat bagi pengunjung untuk bisa mendapatkan tiket masuk ke suatu objek dengan dikenakan biaya, standarnya loket dibuat ditempat yang mudah ditemui biasa terdapat di pintu masuk dan disana sudah terpajang harga/tarif masuk untuk objek wisata, dan biasanya dijaga oleh petugas pelaksanaan/pengelola objek wisata. Loket seharusnya harus terlihat rapid an tertata untuk menambah daya Tarik tiket masuk di buat semenarik mungki dan bertulisan tarifnya, bagi anak-anak bisa di tambahin gambar-gambar yang menarik.

Penambahan Sarana dan Prasarana. Sarana merupakan kelengkapan daerah tujuan wisata yang diperlukkan untuk melayani kebutuhan wisatawan dalam menikmati perjalanan wisatanya, pembangunan sarana harus disesuiakan dengan kebutuhan wisatawan baik secara kuantitatif maupun kualitatif. Adapun sarana secara kuantitatif menunjukan pada jumlah sarana yang harus disediakan oleh pengelola, sedang sarana secara kualitatif menunjukan pada mutu pelayanan yang diberikan yang tercermin pada kepuasan wisatawan yang memperoleh pelayanan. Prasarana merupakan sumber daya alam dan sumber daya buatan manusia yang mutlak dibutuhkan oleh wisatawan dalam perjalanan di daerah tujuan wisata seperti jalan, listrik, air, telekomunikasi. Maka dari itu setiap objek-objek wisata perlu membangun Prasarana yang sesuai dengan kondisi dan lokasi objek wisata. Dapat di simpulkan sangat pentingnya Sarana dan Prasarana untuk mendukung tingkat kunjungan wisatawan terhadap objek wisata, maka dari itu untuk meningkatkan kunjungan di pemandian Lubuk Mata Kucing perlu di bangun Sarana dan Prasarana sebagai berikut :

1.Membuat tempat penyewaan pelampung. Tempat penyewaan merupakan suatu tempat untuk wisatawan dapat meminjam alat-alat keperluan untuk membantunya dalam melakukan kegiatannya dilokasi objek wisata. Sesuai standarnya tempat penyewaan tersebut harus tertata rapid an dijaga oleh orang yang akan menyewakan pelampung dan dituliskan juga harga sewanya agar pengunjung pun mudah mengambil dan membayarnya sesuai yang telah ditentukan bukan suka-suka pengelola yang menetapkan harga yang bervariasi, yang membuat wisata kebingungan.

2.Membuat ruang ganti dan toilet yang nyaman. Toilet merupakan ruangan yang dirancang khusus lengkap dengan kloset, persediaan air dan perlengkapan lainnya yang bersih, aman, dan higienis dimana wisatawan dapat membuang air kecil maupun air besar serta memenuhi kebutuhan fisik, social, psikologis, dan lainnya. Biasanya ruang ganti dan toilet itu di gabung agar pengunjung tidak repot-repot harus keluar masuk, agar pengunjung bisa nyaman tempt nya harus aman agar pengunjung mengganti pakaiannya dengan leluasa dan membuat toilet yang lebih bagus, selalu bersih dan wangi.

3.Membuat tempat istirahat. Merupakan tempat untuk wisatawan dapat beristirahat setelah melakukan kegiatannya dilokasi objek wisata. Supaya membuat wisatawan bisa nyaman ditempat istirahatnya seharusnya tempat tersebut di buat senyaman mungkin yang bisa dibuat untuk berlindung dari paparan sinar matahari maupun hujan dan dibuat di lokasi yang tidak tersembunyi agar wisatawan yang tidak mau 
mandi juga bisa melihat-lihat juga atau bisa memantau anak-anaknya yang sedang bermain-main.

4.Membuat tempat penitipan barang. Merupakan tempat untuk meletakkan barangbarang berharga seperti : Helm, tas, sepatu, sandal, dan lain-lain agar tidak hilang saat melakukan aktivitas di lokasi objek wisata. Tempat penitipan dibuat rapid an tertata agar petugas pun bisa dengan mudah mengambil barang titipan pengunjung dan agar tidak salah pada saat memberikan barang pengunjung diberikan kartu yang berisi nomor tempat petugas meletakkan barangnya, jika hilang maka pengunjung tidak dapat mengambil barang nya, biaya tempat penitipan biasa diluar harga masuk, jadi itu terserah pada pengunjung mau menitipkan barangnya atau tidak ditempat penitipan tersebut :

Penataan Kolam Renang. Pembersihan kolam secara berkala agar kolam selalu bersih dari sampah dedaunan dan lumut sehingga pengunjung pun ingin berenang karena melihat air yang jernih, kalua air nya keruh pasti pengunjung tidak akan mau berenang dilokasi tersebut. Mengelompokkan tempat mandi bagi dewasa, anak-anak agar lebih safety dan mudah untuk dipantau. Membuat permainan untuk anak seperti seluncuran agar anak-anak lebih betah dan nyaman bermain dikolam tersebut.

Infrakstruktur. Infrakstruktur merupakan situasi pendukung fungsi Sarana dan Prasarana, baik yang berupa system pengaturan maupun bangunan fisik diatas permukaan tanah dan dibawah tanah seperti: Sistem pengairan, distribusi air bersih, sistem pembangunan air limbah. Sumber listrik dan energi serta jaringan distribusinya yang merupakan bagian viral bagi terselenggarakan penyediaan Sarana dan Prasarana yang memadai. Sistem jalur angkutan dan terminal yang memadai dan lancar agar memudahkan wisatawan untuk mengunjungi lokasi tempat objek wisata.

\section{Penutup}

Objek Wisata Lubuk Mata Kucing sebenarnya mempunyai potensi tinggi, yang menarik minat para wisatawan dari dalam maupun luar kota Padang Panjang. Lubuk Mata kucing mempunyai daya tarik tersendiri, akan tetapi pemerintah Padang Panjang masih kurang optimal dalam pengembangan potensi yang dimiliki oleh objek wisata tersebut, sehingga belum berjalannya program-program yang yang terkait dengan pengembangan. Belum adanya aturan hukum atau PERDA yang mengatur khusus tentang strategi pengembangan sektor pariwisata di kota Padang Panjang, sehingga rencana-rencana dan program yang dibuat oleh Dispar dengan para koordinasi di lapangan belum bisa dilaksanakan dengan baik dan menyeluruh. Namun dengan optimis, Dispar Padang Panjang tetap menjalankan program-programnya, yang terbukti masih melakukan beberapa pengembangan terhadap pemandian Lubuk Mata Kucing tersebut. Kerjasama pemerintah dengan berbagai Stake Holder sangat penting untuk pengembangan Pemandian Lubuk Mata Kucing, yang dapat menguntungkan antar pihak.

\section{Daftar Pustaka}

Adiwoso, Naning. 2007, Toilet Umum Indonesia, Jakarta, Asosiasi Toilet Indonesia. Bagyono, 2005. Pariwisata dan Perhotelan. Surakarta, Alfabeta.

Syafiie, Inu Kencana, 2009. Pengantar Ilmu Pariwisata. Bandung, Bandar Maju.

Kodhyat, Sejarah Pariwisata dan Perkembangan di Indonesai, Jakarta. PT.Gramedia Widiasa.

Wacik, Jero, 2008. Panduan Pelaksanaan Sadar Wisata, Jakarta. Departemen Kebudayaan dan Pariwisata. 
Oka A. Yoeti, 1992. Pengantar Ilmu Pariwisata. Bandung. Angkasa Offset. , 2008. Perencanaan dan Pengembangan Pariwisata. Bandung. Angkasa.

Suwantoro, Gamal, 1997. Dasar-Dasar Pariwisata, Yogyakarta. Andi Yogyakarta.

Sugiono, 2008. Ilmu Pariwisata, Jakarta, Pradya Paramita. 